\title{
Late-Onset Homozygous Protein C Deficiency Manifesting Cerebral Infarction as the First Symptom at Age 27
}

\author{
Katsumi Deguchi, Tetsuya Tsukada*, Eiichi Iwasaki*, Hideo Wada*, Seiko Murashima**, \\ Masao MrYazaki*** and Shigeru ShIRAKaWA*
}

\begin{abstract}
We report a 31-year-old female who had repeated thrombosis and was diagnosed as having congenital homozygous protein $\mathrm{C}$ deficiency based on decreased protein $\mathrm{C}$ antigen and activity, and the findings of family history. This patient had shown no symptom of thrombosis until the age of 27 years, when she had cerebral infarction as the first symptom. Low molecular weight heparin was useful for disseminated intravascular coagulation (DIC) that complicated protein $\mathrm{C}$ deficiency in this patient.
\end{abstract}

(Internal Medicine 31: 922-925, 1992)

Key words: DIC, thrombosis, low molecular weight heparin, cerebrovascular disease

\section{Introduction}

Congenital protein $\mathrm{C}$ deficiency is a genetic disorder that predisposes to thrombosis and embolism (1). We encountered a 31-year-old female who was diagnosed as having congenital homozygous protein $\mathrm{C}$ deficiency based on decreased protein $\mathrm{C}$ antigen and activity, and the findings obtained by the family history. Disseminated intravascular coagulation (DIC) was also diagnosed according to the diagnostic criteria of DIC proposed by the Research Group of the Ministry of Health and Welfare was treated with low molecular weight heparin (LMW heparin).

\section{Case Report}

A 31-year-old female was admitted to our hospital with repeated thromboses. She was well until the age of 27, when she developed disturbance of consciousness while riding a bicycle in 1986. In March 1988, she developed disturbance of consciousness followed by abnormal behavior during housework at the age of 30 . Computed tomography (CT) scanning of the head showed cerebral infarction on the left temporal lobe. In the mid-June 1989 , she was admitted to another hospital due to increased abdominal pain, watery diarrhea, and vomiting and underwent an operation for necrosis in the sigmoid colon. On July 4, of the same year, left abdominal pain and mucoid bloody feces appeared, and she underwent an operation at this hospital under the diagnosis of thrombosis in the inferior mesenteric vein. On August 30, pain and swelling in the bilateral limbs developed, and venography of the lower limbs showed deep venous thrombosis peripheral to the thigh. Anti-platelet therapy and treatment with urokinase, heparin, and prostaglandin $\mathrm{E}_{1}\left(\mathrm{PGE}_{1}\right)$ improved the symptoms. Since such thrombosis frequently recurred, she was referred to our hospital on the suspicion of a congenital coagulation abnormality.

In past illness, no abnormalities were detected at her birth and during growth. She had never taken contraceptive pills. In 1986 (at the age of 27 years), she underwent an operation for tubal rupture, but preoperative examination showed no abnormal findings. In familial history, her parents were second cousins (Fig. 1). Her mother died of cerebral thrombosis at the age of 35 years, her paternal grandfather died of cerebrovascular disease (CVA), and her brother died immediately after birth.

On admission, she was $150 \mathrm{~cm}$ tall and weighed $67 \mathrm{~kg}$. Her body temperature was $36.6^{\circ} \mathrm{C}$. No anemia or jaundice was observed. The chest was normal. In the abdomen, surgical wounds were present, but no tenderness or resistance was noted. The liver, spleen, and kidneys were not palpable. The lower limbs were swollen but showed no flare or tenderness. There were no neuro-

\footnotetext{
From the Mie University College of Medical Sciences, Tsu, *the Second Department of Internal Medicine, Mie University School of Medicine, Tsu, **the Mie Nursing College, Tsu and ${ }^{* * *}$ the Department of Neurology, Yamada Red Cross Hospital, Mizono

Received for publication October 24, 1991; Accepted for publication March 18, 1992

Reprint requests should be addressed to Dr. Katsumi Deguchi, the Second Department of Internal Medicine, Mie University School of Medicine, 174, 2-chome, Edobashi, Tsu 514, Japan
} 


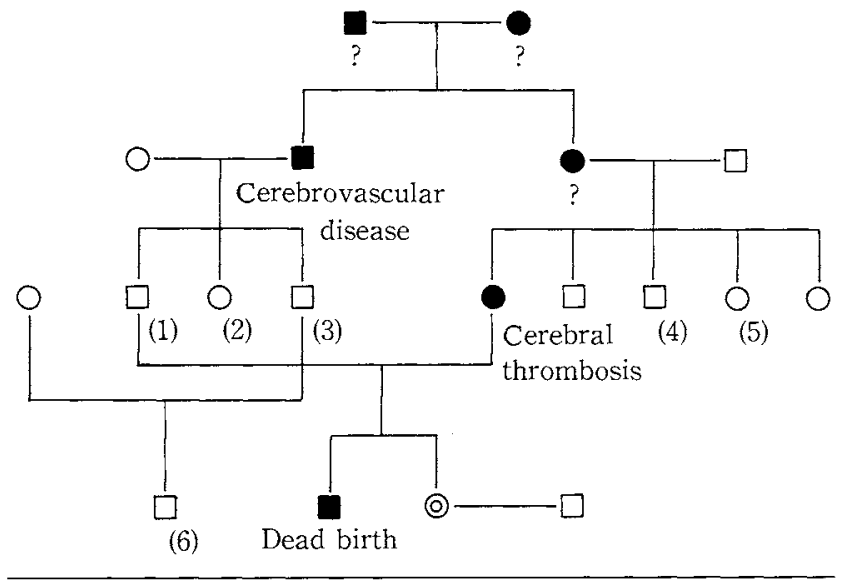

\begin{tabular}{|c|c|c|c|}
\hline \multicolumn{4}{|c|}{ Protein $\mathrm{C}$} \\
\hline & \multicolumn{2}{|c|}{ Antigen } & \multirow{2}{*}{ 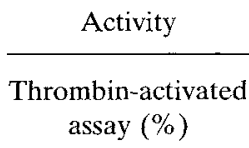 } \\
\hline & $\begin{array}{c}\text { Laurell's } \\
\text { method (\%) }\end{array}$ & $\begin{array}{c}\text { EIA } \\
(\mu \mathrm{g} / \mathrm{m} \mathrm{l})\end{array}$ & \\
\hline Patient & 0 & 0.3 & 5 \\
\hline Family (1) & 40 & 1.8 & 44 \\
\hline (2) & 45 & 1.7 & 47 \\
\hline (3) & 76 & 2.8 & 73 \\
\hline (4) & 56 & 2.0 & 44 \\
\hline (5) & 69 & 2.6 & 60 \\
\hline (6) & 100 & 4.4 & 170 \\
\hline
\end{tabular}

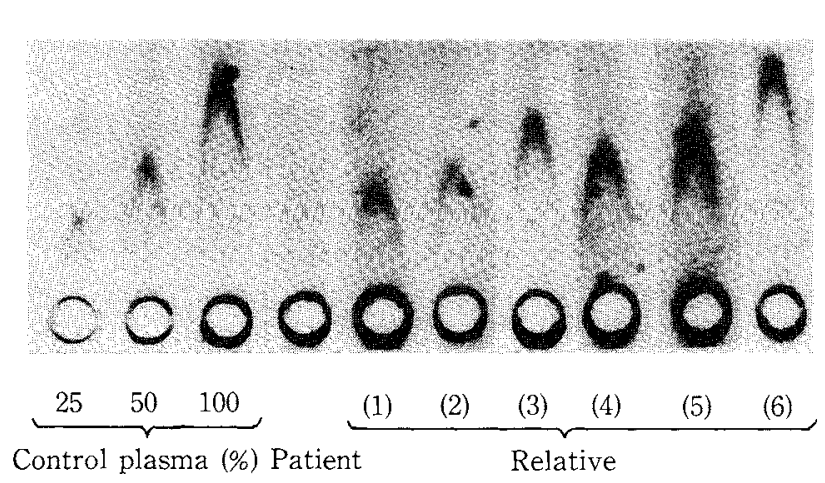

Fig. 1. Pedigree of the patient's family. Family members number $3,4,5$ and 6 are thought to show partial deficiency (heterozygous protein $\mathrm{C}$ deficiency). Closed symbols and a double circle show the deceased members and propositus, respectively. The levels of protein $\mathrm{C}$ antigen and enzyme activity are indicated in the table. The patient's father, uncles and aunts showed decreased levels of protein $C$ antigen and activity.

logical abnormalities.

Analysis of urine and feces showed no abnormalities (Table 1). The erythrocyte sedimentation rate was $1 \mathrm{~mm} / \mathrm{h}$. Though slight anemia was observed, the leukocyte and platelet counts were normal. Blood biochemical and serological examinations showed no abnormal findings. Coagulation tests showed activated partial thromboplastin time (APTT) of 41.3 seconds, prothrombin time (PT) of 16.8 seconds $(29 \%)$, thrombotest (TT) of $14.0 \%$, and fibrinogen $(\mathrm{Fbg})$ of $83 \mathrm{mg} / \mathrm{dl}$
(Table 2). The plasma level of each coagulation factor was nearly normal. However, the fibrinogen and fibrin degradation product (FDP) level was $29.2 \mu \mathrm{g} / \mathrm{ml}$, and the D-dimer $24.9 \mu \mathrm{g} / \mathrm{ml}$ (normal value $0-0.5 \mu \mathrm{g} / \mathrm{ml}$ ). FM test also showed a positive result. Regarding the factors inhibiting the coagulation, the antithrombin III (AT III) was $110 \%$, but the protein $\mathrm{C}$ antigen level was less than $0.3 \mu \mathrm{g} / \mathrm{ml}$ by the one-step sandwich enzyme immunoassay using a monoclonal antibody which recognizes the Gladomain of protein C (Teijin, TD-82) (normal value $2.76-3.76 \mu \mathrm{g} / \mathrm{ml})(2)$ and below the detection limit by Laurell's rocket immuno-electrophoresis (3). Protein C activity was less than $5 \%$, which was determined by using protein $\mathrm{C}$-deficient plasma and the protein $\mathrm{C}$ activator (4), but the protein $S$ antigen was $110 \%$. The decrease of platelet aggregation by collagen and arachidonic acid was probably due to the anti platelet drugs administered at the previous hospital. These findings suggested protein C deficiency and DIC.

DIC was improved with treatment with AT III preparation $(1,500 \mathrm{U})$ and LMW-heparin $(5,000 \mathrm{U} /$ day $)$. Warfarin $(4 \mathrm{mg} /$ day) was used in combination with LMW-heparin to discontinue the latter. However, thrombin/antithrombin III complex (TAT), D-dimer and plasmin- $\alpha_{2}$ plasmin inhibitor complex (PIC) gradually increased, and flare, pain, and heat sensation appeared 3 days after the initiation of warfarin administration, and thrombophlebitis developed at upper limbs. Radioisotope fibrinogen uptake study revealed the development of thrombi in the vein of upper limbs. Therefore, the dose of warfarin was reduced to $2 \mathrm{mg} /$ day, and LMWheparin was continuously used. In addition, fresh frozen plasma (FFP) was administered. Thrombophlebitis improved. At present, ticlopidine is used in combination with these drugs, and no symptoms of thrombosis have been observed.

\section{Familial investigation}

The protein $\mathrm{C}$ antigen and activity levels in family members who could be investigated are shown in Fig. 1. Her father showed a protein $\mathrm{C}$ antigen level of $40 \%$ (Laurell's method) (3) and $1.8 \mu \mathrm{g} / \mathrm{ml}$ (EIA) (2), and a protein C activity of $44 \%$ (thrombin-activated assay) (4). The paternal and maternal uncles and aunts had no history of thrombosis but showed decreased protein $\mathrm{C}$ antigen and activity. The degree of the decrease was less marked in the maternal uncle and aunt.

\section{Discussion}

This patient developed transient disturbance of consciousness while pedaling a bicycle at the age of 27 years, left temporal lobe infarction at 30 years, and thromboses in the inferior mesenteric vein and a deep vein in the lower limbs at the age of 31 . Examinations to clarify the cause of this frequent thrombosis showed a protein $\mathrm{C}$ 
Deguchi et al

Table 1. Laboratory Data on Admission

\begin{tabular}{|c|c|c|c|c|c|}
\hline Urinarysis & \multicolumn{3}{|c|}{ Blood chemistry } & \multirow{2}{*}{$\begin{array}{l}\mathrm{Na} \\
\mathrm{K}\end{array}$} & \multirow{2}{*}{$\begin{array}{c}140 \mathrm{mEq} / \mathrm{l} \\
4.0 \mathrm{mEq} / 1\end{array}$} \\
\hline protein & $(-)$ & $\mathrm{TP}$ & $6.3 \mathrm{~g} / \mathrm{d} 1$ & & \\
\hline glucose & $(-)$ & $\mathrm{Alb}$ & $3.9 \mathrm{~g} / \mathrm{dl}$ & $\mathrm{Cl}$ & $108 \mathrm{mEq} / 1$ \\
\hline blood & $(-)$ & T-Bil & $0.3 \mathrm{mg} / \mathrm{dl}$ & $\mathrm{Ca}$ & $8.8 \mathrm{mg} / \mathrm{dl}$ \\
\hline \multirow[t]{2}{*}{ ketone } & $(-)$ & D-Bil & $0.1 \mathrm{mg} / \mathrm{dl}$ & $\mathbf{P}$ & $3.6 \mathrm{mg} / \mathrm{dl}$ \\
\hline & & GOT & 26IU/1 & & \\
\hline \multirow{3}{*}{$\begin{array}{l}\text { Occult bloo } \\
\text { of stool }\end{array}$} & & GPT & $23 \mathrm{IU} / \mathrm{l}$ & \multicolumn{2}{|l|}{ Serological test } \\
\hline & $(-)$ & $\mathrm{LDH}$ & $138 \mathrm{IU} / \mathrm{l}$ & CRP & $<0.26 \mathrm{mg} / \mathrm{dl}$ \\
\hline & & ALP & $136 \mathrm{IU} / 1$ & RPR & $(-)$ \\
\hline \multirow[t]{2}{*}{ ESR } & $1 \mathrm{~mm} / \mathrm{h}$ & $\gamma$-GTP & $290 \mathrm{IU} / 1$ & TPHA & $(-)$ \\
\hline & & $\mathrm{Ch}-\mathrm{E}$ & $0.98 \Delta \mathrm{pH}$ & ANA & $(-)$ \\
\hline \multicolumn{2}{|c|}{ Peripheral blood } & $\mathrm{CPK}$ & $27 \mathrm{IU} / \mathrm{I}$ & $\mathrm{RA}$ & $(-)$ \\
\hline $\mathrm{RBC}$ & $341 \times 10^{4} / \mu l$ & FBS & $87 \mathrm{mg} / \mathrm{dl}$ & & \\
\hline $\mathrm{Hb}$ & $11.2 \mathrm{~g} / \mathrm{dl}$ & T-Chol & $208 \mathrm{mg} / \mathrm{dl}$ & & \\
\hline $\mathrm{Ht}$ & $34.9 \%$ & TG & $52 \mathrm{mg} / \mathrm{dl}$ & & \\
\hline Ret & $1.1 \%$ & BUN & $12 \mathrm{mg} / \mathrm{dl}$ & & \\
\hline WBC & $4,170 / \mu 1$ & Crea & $1.1 \mathrm{mg} / \mathrm{dl}$ & & \\
\hline Plat & $18.4 \times 10^{4} / \mu \mathrm{l}$ & UA & $5.1 \mathrm{mg} / \mathrm{dl}$ & & \\
\hline
\end{tabular}

Table 2. Hemostatic Test

\begin{tabular}{lclc}
\hline APTT & $41.3 \mathrm{~s}$ & ELT & $9.5 \mathrm{~h}$ \\
PT & $16.8 \mathrm{~s}$ & FDP & $29.2 \mu \mathrm{g} / \mathrm{ml}$ \\
TT & $14.0 \%$ & D-dimer & $24.9 \mu \mathrm{g} / \mathrm{mI}$ \\
Fibrinogen & $83 \mathrm{mg} / \mathrm{dl}$ & FM & $(+)$ \\
Factor II & $80 \%$ & Plasminogen & $87.6 \%$ \\
Factor V & $93 \%$ & $\alpha_{2}$ PI & $73.4 \%$ \\
Factor VII & $70 \%$ & Bleeding time & $3 \mathrm{~min}$ \\
Factor VIII & $68 \%$ & Plat retention & $39.1 \%$ \\
Factor IX & $52 \%$ & Plat aggregation & \\
Factor X & $76 \%$ & ADP & $45 \%$ \\
Factor XI & $57 \%$ & Adrenaline & $11 \%$ \\
Factor XII & $57 \%$ & PAF & $59 \%$ \\
PIVKA II & $<1 \%$ & Arachid. A & $0 \%$ \\
AT III & $110 \%$ & RIPA & $82 \%$ \\
Protein C & & & \\
activity & $5 \%$ & Cardiolipin antibody & \\
antigen & $0.3 \mu \mathrm{g} / \mathrm{ml}$ & IgG & $(-)$ \\
Protein S & & IgM & $(-)$ \\
antigen & $110 \%$ & & \\
\hline
\end{tabular}

antigen level of less than $0.3 \mu \mathrm{g}$ (EIA) and below the detection limit (Laurell's method) (Table 2), and a protein $\mathrm{C}$ activity of less than $6 \%$ (coagulation method). These findings suggested protein $\mathrm{C}$ deficiency. This deficiency was considered to be the cause of the frequent thrombosis. In her family history, her mother died of cerebral thrombosis, and paternal grandfather died of CVA. In addition her father showed $40 \%$ (Laurell's method) and $1.8 \mu \mathrm{g} / \mathrm{ml}$ (EIA) protein $\mathrm{C}$ antigen, and $44 \%$ in the activity of protein C (coagulation method). The paternal and maternal uncles and aunts had no history of thrombosis but showed decreased protein C antigen and activity. These results suggest that protein $\mathrm{C}$ deficiency in the proband was inherited from both paternal and maternal sides. i.e., homozygous.

Homozygous protein $\mathrm{C}$ deficiency has been reported to develop during the neonatal period and to be a severe disease repeatedly inducing purpura fulminans $(5,6)$. However, Manabe and Matsuda reported a patient with homozygous protein $\mathrm{C}$ deficiency who showed no symptoms during the neonatal period but developed venous thrombosis at the age of 14 years (7). In the present patient, symptoms suggestive of thrombosis appeared at the age of 27 years, and a definite diagnosis was made at the age of 31 years. The patient reported by Manabe and Matsuda (7) and our patient suggest that homozygous protein $\mathrm{C}$ deficiency sometimes produces no symptoms during childhood. Repeated purpura fulminans has also been reported in heterozygous protein $\mathrm{C}$ deficiency and is not always specific to homozygous deficiency (8). The development of symptoms of protein $\mathrm{C}$ deficiency or abnormality may be affected by the degree of impairment of hemostatic homeostasis in the body caused by quantitative and qualitative protein $\mathrm{C}$ abnormalities.

DIC complicating congenital protein $\mathrm{C}$ deficiency has been reported in patients with purpura fulminans who developed protein $\mathrm{C}$ deficiency during the neonatal period $(5,9-16)$. Our patient also showed on admission prolonged PT, decreased fibrinogen and increased FDP, fulfilling the criteria of DIC by the Research Group of the Ministry of Health and Welfare. LMW-heparin administration decreased TAT, D-dimer, and PIC. These results suggest the usefulness of LMW-heparin for DIC.

\section{References}

1) Griffin JH, Evatt B, Zimmerman TS, et al. Deficiency of protein $\mathrm{C}$ in congenital thrombotic disease. J Clin Invest 68: 1370, 1981.

2) Wakabayashi $K$, Sakata $Y$, Aoki N. Conformation-specific monoclonal antibodies to the calcium-induced structure of protein $\mathrm{C} . \mathrm{J}$ Biol Chem 261: 11097, 1986.

3) Laurell CB. Electroimmunoassay. Scand J Clin Lab Invest 29 (Suppl 124): 21, 1977.

4) Martinoli JL, Stocker K. Fast functional protein $\mathrm{C}$ assay using PROTAC, a novel protein $C$ activator. Thromb Res 43: 253, 


\section{Homozygous Protein C Deficiency}

1986.

5) Branson HE, Marble R, Katz J, et al. Inherited protein C deficiency and coumarin-responsive chronic relapsing purpura fulminans in a newborn infant. Lancet 2: 1165, 1983.

6) Sills RH, Marlar RA. Montgomery RR, et al. Severe homozygous protein C deficiency. J Pediatr 105: 409, 1984.

7) Manabe S, Matsuda M. Homozygous protein $\mathrm{C}$ deficiency combined with heterozygous dysplasminogenemia found in a 21-yearold thrombophilic male. Thromb Res 39: 333, 1985.

8) Oka T, Suzuki Y, Hiramoto A, et al. Severe heterozygous protein $\mathrm{C}$ deficiency with relapsing purpura fulminance from the newborn period. Jpn J Clin Hematol 27: 1971, 1986.

9) Marciniak E, Wilson HD, Marlar RA. Neonatal purpura fulminans as expression of homozygosity for protein $\mathrm{C}$ deficiency. Blood 62: 303, 1983

10) Sills RH, Hombert JR, Montgomery RR. Clinical course and therapy of an infant with severe homozygous protein $\mathrm{C}$ deficiency. Blood 62: 310, 1983.
11) Estelle's A, Garcia-Plaza I, Dasi' A, et al. Severe inherited "homozygous" protein C deficiency in a newborn infant. Thromb Haemost 52: 53, 1984.

12) Garcia-Plaza I, Jimenez-Astorga C, Borrego D, et al. Coumarin prophylaxis for fulminant purpura syndrome due to homozygous protein C deficiency. Lancet 16: 634, 1985.

13) Yuen $P$, Cheung $A$, Ju Lin $H$, et al. Purpura fulminans in a Chinese boy with congenital protein $\mathrm{C}$ deficiency. Pediatr 77: $670,1986$.

14) Hurtman KR, Manco-Johnson M, Rawlings JS, et al. Homozygous protein $\mathrm{C}$ deficiency: Early treatment with warfarin. Am J Pediatr Hematol Oncol 11: 395, 1989.

15) Auletta MJ, Headington JT. Purpura fulminans - A cutaneous manifestation of severe protein C deficiency. Arch Dermatol 124: 1387, 1988.

16) Murlar RA, Montgomery R, Broekmans A. Diagnosis and treatment of homozygous protein $\mathrm{C}$-deficient children. J Pediatr 114: 528, 1989. 